\title{
Audit Committee Characteristics and Timeliness of Corporate Financial Reporting in the Nigerian Insurance Industry
}

\author{
Gospel J. Chukwu ${ }^{1 *}$, Ngozi Nwabochi ${ }^{2}$ \\ ${ }^{I}$ Department of Accountancy, Ken Saro Wiwa Polytechnic, Bori, Rivers State, Nigeria \\ ${ }^{2}$ Department of Accountancy, Ignatius Ajuru University of Education, Rumuolumeni, Port Harcourt, Nigeria \\ *Corresponding Author: Gospel J. Chukwu, Department of Accountancy, Ken Saro Wiwa Polytechnic, \\ Bori, Rivers State, Nigeria
}

\begin{abstract}
The purpose of this study is to investigate the effect of the characteristics of audit committee on timeliness of corporate financial reporting in the Nigerian insurance industry. The study employed ex post facto research design, and used secondary data extracted from the annual reports of fifteen insurance firms listed on the Nigerian Stock Exchange during the period 2012 to 2015 . Four hypotheses were formulated and tested using the Ordinary Least Square method of multiple regressions. Results revealed a significantly negative relationship between audit committee meeting frequency and timeliness of corporate financial reporting. Also, there was a negative but insignificant association between audit committee gender, as well as audit committee independence, and corporate financial reporting. Finally, the results showed that audit committee size was positively and statistically, insignificantly related to timelines $23 \mathrm{~s}$ in corporate financial reporting. The study has implications for insurance firms seeking timely release of financial reports. It recommended that insurance firms should increase the frequency of meetings of the audit committee and perform more due diligence on prospective independent and female members of the audit committees.
\end{abstract}

Keywords: Insurance Industry, Reporting Timeliness, Audit Committee Size, Independence, Gender Diversity, Meeting Frequency

\section{INTRODUCTION}

The objective of financial reporting is to provide accounting information to assist users of financial statements to assess the amount, timing and uncertainty of entity's future cash inflow and cash outflow so as to make informed decision. For accounting information to be decision useful, The International Accounting Standards Board [IASB] requires that the financial information provided by the report must possess certain fundamental and enhancing characteristics. One of the key enhancing characteristics is timeliness. International Accounting Standard Board defines timeliness as the availability of information (needed by decision makers for useful decision making)in time to be able to influence decisions [1]. Extant literature uses the number of days between firm year and the date the external auditor signs the financial statements as proxy of timeliness of financial reporting.

Prior studies on timeliness of corporate financial reporting for non-financial firms indicate that a number of factors determine the timeliness of corporate financial reporting. These include firm size, profitability, leverage, financial year end, listing status, industry sector, quality of internal control, dividend, ownership, company age, financial conditions, presence of contingencies, presence of extraordinary items, audit risks, audit complexity, correction of earnings [2,3,4,5,6,7,8,9,10, $11,12,13,14,15,16,17,18,19,20]$.

Audit risks, audit complexity and quality of internal control are audit related issues in financial reporting. The Companies and Allied Matters Act, 2004 vests the audit committee with the responsibility of overseeing the financial reporting process. Prior studies provide evidence linking the effectiveness of audit committees to the characteristics of the committee [21,22]. The characteristics of audit committee usually cited are size, independence, meeting frequency and gender diversity $[23,24,25]$. To what extent these characteristics are associated with timeliness of financial reporting is the focus of this study. The study focuses on the insurance sub sector because of paucity of literature in this sub sector. Prior studies usually exclude the financial sector especially the insurance sub sector. The argument has always been that the financial services sector has unique reporting requirements. 
The insurance sub sector is very vital to the economic development of Nigeria. Insurance companies promote socio-economic activities through risk transfer and indemnification for companies and individuals as well as mobilization of long term funds. Yet insurance firms fail to submit annual accounts in timely manner and investors hold poor perception about the Nigerian insurance industry [26,27]. Timely availability of financial reports may help improve investors' perception.

This study makes three contributions to knowledge. First the result broadens our understanding of the specific channel in which audit committee affects the financial reporting quality. Second, it affords insurance firms evidence on which attributes of audit committee affect timeliness of financial reporting. Third, it reduces the paucity of literature in the sub sector.

\section{LITERATURE REVIEW}

\subsection{Conceptual Review}

\subsubsection{Insurance Industry}

Insurance firms, as financial intermediaries, in the Nigerian financial services sector provide vital support to the socio-economic development of the country. Ebirien and Nwanyanwu [28] summarize the main function of insurance companies as the promotion of socio-economic activities through risk transfer and indemnification for companies and individuals as well as long term fund mobilization.

As at December 31, 2016 there were fifty insurance firms in Nigeria and twenty eight were listed on the Nigerian Stock Exchange. The Insurance Act 2003 provides for the establishment of the National Insurance Commission (NAICOM) as the apex regulator of the insurance industry in Nigeria. It sets forth copious provisions for the industry amongst which is audit and publication of financial statements. However, the insurance firms are also required to comply with the financial reporting requirements in the Companies and Allied Matters Act 2004 and the Listing Rules of the Nigerian Stock Exchange for listed entities.

\subsubsection{Timeliness}

Timeliness is an important qualitative characteristics of financial report and the IASB [1] defines it as "having information available to decision-makers in time to be capable of influencing their decisions" [QC29]. Timeliness is so important that the regulators set the dead line for submission and publication of audited financial statements. Specifically, the CAMA 2004 and the Listing Rules set 120 days after year-end as deadline for submission and publication of audited financial statements. The Insurance Act 2003 provides not more than six months after year-end for insurance firms to submit and publish the audited accounts. Timeliness is of great significance to investors since it curtails information asymmetry [12] and promotes market discipline through reduction in information leakages, rumours and insider abuses [5, 29, 30].

\subsubsection{Audit Committee}

The CAMA 2004 provides that each listed firm should establish an audit committee with membership not exceeding 6 and spread equally between shareholders and directors. It further provides that the members of the committee be elected at an annual general meeting. The functions of the committee according to CAMA are to:

- Ascertain whether the accounting and reporting policies of the company are in accordance with legal requirements and agreed ethical practices.

- Review the scope and planning of audit requirements.

- Review the findings of management matters in conjunction with external auditors and departmental responses thereon.

- Keep under review the effectiveness of the company's system of accounting and internal control.

- Make recommendations to the board in regard to the appointment, removal and remuneration of the external auditors of the company.

- Authorize the internal auditors to carry out investigations into any activities of interest or concern to the committee. 


\subsection{Theoretical Framework}

This study draws from the agency theory to explain the relationship between audit committee characteristics and timeliness of corporate financial reporting. Under the agency relationship, the owners (shareholders) delegate day to day management of the firm to the managers (agents)[31]. Agency theory posits that there is a potential goal conflict in agency relationship such that the manager would pursue his goal at the expense of the owner. Such goal conflict could manifest in excessive consumption of perquisites, shirking responsibility [32], sub optimal investment decision for empire building [33] and hoarding of vial information [34]. To mitigate agency costs agency theorists recommend the institutionalization of corporate governance mechanisms amongst which is the audit committee.

\subsection{Empirical Review}

\subsubsection{Audit Committee Siz}

The CAMA 2004 provides that audit committee size should not exceed six. Audit committee size is important because it signals the significance attached to the committee[35]. An audit committee with large membership is blessed with different viewpoints in deliberating on financial reporting issues. It also enables the committee to handle several financial reporting issues simultaneously thereby leading to timely completion of external audit. However, large size audit committee encounters free riders problem and difficulties in co-ordination. This suggests small size is preferable. Pucheta-Martinez and Fuentes [36] find that audit committee size affected the financial reporting quality of Spanish firms. Rahmat, Iskandar, \&Saleh [37] document similar evidence in a sample of Malaysian firms. The above discussion leads to the first hypothesis stated thus:

Ho1: Audit committee size is negatively related to timelines of corporate financial reporting.

\subsubsection{Audit Committee Independence}

The audit committee is composed of directors and representatives of shareholders in line with the provisions of the CAMA 2004. The reason for the inclusion of shareholders is to strengthen the independence of the committee. Audit committee is usually considered to be independent if the members of audit committee are free from any relationship that might impair, or might appear to impair, their judgment. Generally the literature considers uses the proportion of non-executive and independent directors on the audit committee as proxy of audit committee independence. Prior studies find evidence of relationship between independence of members of audit committee and financial reporting quality. Abbot, Parker and Peters [38] provide evidence of a significant negative association between audit committee independence and financial restatement. Similarly, Bedard, Chtourou and Courteau [39] find a negative association between audit committee independence and the likelihood of a reduction in aggressive earnings management. In line with the above discussions, a second hypothesis is formulated and stated thus:

Ho2. Audit committee independence is negatively associated with timeliness in corporate financial reporting.

\subsubsection{Audit committee Meeting Frequency.}

Another characteristics of audit committee considered in the literature as a determinant of the effectiveness of the committee is frequency of meetings. The NAICOM Code of Corporate Governance [40] recommends that audit committee meets at least three times annually. It is contended that an audit committee that meets frequently are effective. Prior studies use the number of committee meetings held annually as a proxy for committee diligence [41, 42, 43]. Frequency of committee meetings affords the audit committee more time to have more oversight over the financial reporting process and this will impact negatively on timeliness. Abbot et al [38] report that frequency of audit committee meeting is negatively associated with probability of restatement. Karamanou and Vafeas [43] find frequency of audit committee meetings to be associated with more management earnings forecasts. Mohamad-Nor, Shafie, \& Wan-Hussein [24] also provide evidence in support of frequent audit committee meetings and likelihood of timely production of audit report.

Consequently the following hypothesis is formulated: 
Ho3: The frequency of meetings of the audit committee is negatively associated with timeliness.

\subsubsection{Audit Committee Diversity}

Since the Beijing Conference in 1995, there has been a steady demand for female representation on corporate boards. Resource dependency theorists are of the view that inclusion of women on the board would afford the firm different ideas, views and experience. Gender advocates argue that women should sit on the monitoring committees such as the audit committee because they are good monitors [44]. Adams and Ferreira [45] find support in this direction. Gul, Srinidhi and Ng [46]also find evidence which suggests that gender diversity facilitates private information collection even in firms. Consequently this study presents the following hypothesis:

Ho4. Audit committee gender diversity is negatively associated with timeliness of corporate financial reporting.

\subsection{Control Variables}

Drawing from previous studies $[3,4 ; 11,12,14,17,20,30,47]$ the study controls for profitability, leverage and firm size. It is contended that managers of profitable firms are more eager to disclose more information to distinguish themselves from loss making firms. Kothari, et al [34] provide evidence that managers withhold bad news - losses. The paper therefore expects a negative relationship between profitability and timeliness in corporate financial reporting. The market views firms with high leverage as very risky and so managers of such firms would not encourage timely completion and publication of financial reports. A positive relationship between leverage and corporate financial reporting is therefore expected. Firm size affects timeliness. Large firms have enough resources to support the audit committee, institute adequate and effective internal control system, all geared toward ensuring timely completion of external audit and subsequent publication in the national dailies. Furthermore, large firms face greater political scrutiny andto avoid political intervention, they have to support timely completion of audit and publication of same. Therefore a negative relationship between firm size and timeliness is expected.

\section{MeThOdologY}

\subsection{Research Design and Data}

This study adopts ex post facto research design by utilizing secondary data obtained from annual reports of insurance firms. The study covered the period 2012 to 2015. This period was considered appropriate for the study because it contained most recent data in post IFRS regime.

\subsection{Population and Sample}

The population of the study comprised all the twenty eight insurance firms listed on the Nigerian Stock Exchange as at December 31, 2015 according to the Fact Book of the Nigerian Stock Exchange. Based on Taro Yamen's formula, the study established twenty six insurance firms as the expected sample size.

Taro Yamen's formula is

$$
n=\frac{N}{1+(e)^{2}}
$$

Where:

$$
\begin{aligned}
& n=\text { sample size sought } \\
& e=\text { level of significance } \\
& N=\text { Population size }
\end{aligned}
$$

To form the sample for the study, the insurance firm must in each year have annual report with complete data for regression. The study excluded thirteen insurance firms because of incomplete information thereby yielding a final sample of fifteen insurance firms and 60 firm-year observations for the period 2012 to 2015 . Table 1 presents the sample selection procedure. 
Audit Committee Characteristics and Timeliness of Corporate Financial Reporting in the Nigerian Insurance Industry

Table1. Sample selection procedure

\begin{tabular}{|l|l|l|l|}
\hline \multicolumn{1}{|c|}{ Year } & \multicolumn{1}{c|}{ Description } & \multicolumn{1}{c|}{ No of DMBs } & \multicolumn{1}{c|}{ Firm years } \\
\hline 2015 & Population & 28 & 112 \\
\hline $2012-2015$ & Less firms without complete data & 13 & 52 \\
\hline $2012-2015$ & Final sample & 15 & 60 \\
\hline
\end{tabular}

Source: Authors' computations (2019)

\subsection{Model Specification}

The study models timeliness as a function of audit committee characteristics and control variables. The model is:

AUDLAG $=f($ ACSZ, ACIND, ACMEET,ACGENDIV, PROF, LEV , FSZE).

Explicitly the model is stated thus:

$$
\begin{aligned}
\text { AUDLAG }_{\mathrm{i}, \mathrm{t}}=\quad & \beta_{0+} \beta_{1} \mathrm{ACSZ}_{\mathrm{i}, \mathrm{t}}+\beta_{2} \mathrm{ACIND}_{\mathrm{i}, \mathrm{t}} \beta_{3} \mathrm{ACMEET}_{\mathrm{i}, \mathrm{t}}+\beta_{4} \mathrm{ACGENDIV}_{\mathrm{i}, \mathrm{t}}+ \\
& \beta_{5} \mathrm{PROF}_{\mathrm{i}, \mathrm{t}}+\beta_{6} \mathrm{LEV}_{\mathrm{i}, \mathrm{t}}+\beta_{8} \mathrm{FSZE}_{\mathrm{i}, \mathrm{t}}+\varepsilon_{\mathrm{i}}
\end{aligned}
$$

Where for insurance firm $\mathrm{i}$ at year $\mathrm{t}$ :

\begin{tabular}{|l|l|}
\hline AUDLAG & $\begin{array}{l}\text { Audit lag as a measure of timeliness. It is measured as the number of days between the } \\
\text { year-end and the date the auditor signs the audit report. }\end{array}$ \\
\hline ACSZ & Number of members of the audit committee \\
\hline ACIND & $\begin{array}{l}\text { Audit committee independence, measured as the number of non-executive directors on } \\
\text { the audit committee. }\end{array}$ \\
\hline ACMEET & $\begin{array}{l}\text { Meeting frequency, measured as number of meetings held annually by the audit } \\
\text { committee. }\end{array}$ \\
\hline ACGENDIV & $\begin{array}{l}\text { Audit committee gender, measured by the number of female members of the audit } \\
\text { committee. }\end{array}$ \\
\hline PROF & $\begin{array}{l}\text { Profitability, proxied by return on assets and calculated as profit before tax divided by } \\
\text { total assets }\end{array}$ \\
\hline LEV & Leverage, measured as total liabilities divided by total assets \\
\hline FSZE & Firm size, computed as natural log of total assets \\
\hline E & Error term \\
\hline$\beta_{0,} B_{1 . .} \beta_{7}$ & Intercept, Regression coefficients \\
\hline
\end{tabular}

\section{RESULTS AND DISCUSSION}

\subsection{Descriptive Statistics}

Table 2 presents the descriptive statistics of the study. Table 2 shows 159 days after year end as the mean reporting days. It took a maximum of 408 days after year end for some insurance firms to have audited financial statements. This means that users of financial statements of such firms were denied financial information for over one year. This is in total contravention of the provisions of CAMA 2004and the Insurance Act 2003 as well as the Listing Requirement of the Nigerian Stock Exchange.

Table2. Descriptive statistics

\begin{tabular}{|l|l|l|l|l|l|}
\hline \multicolumn{1}{|c|}{ Variable } & \multicolumn{1}{c|}{ Obs } & \multicolumn{1}{c|}{ Mean } & \multicolumn{1}{c|}{ Std. Dev. } & \multicolumn{1}{c|}{ Min } & \multicolumn{1}{c|}{ Max } \\
\hline Audlag & 60 & 159.3833 & 92.86113 & 29 & 408 \\
\hline acsz & 60 & 5.466667 & .891897 & 4 & 6 \\
\hline Acind & 60 & 2.366667 & .7122813 & 1 & 3 \\
\hline Acmeet & 60 & 3.766667 & .9454022 & 2 & 7 \\
\hline Acgendiv & 60 & .5666667 & .620734 & 0 & 2 \\
\hline Prof & 60 & .0318327 & .0728072 & -.256769 & .22284 \\
\hline Lev & 60 & .5359365 & .2046949 & .116094 & 1.253543 \\
\hline Fsze & 60 & 16.68261 & 1.282921 & 15.4976 & 22.62205 \\
\hline
\end{tabular}

Source: Authors' computations (2019)

An average of two non-executive directors sit on the audit committee suggesting high level of independence giving allowable maximum of three directors. On the average, the audit committees of 
Audit Committee Characteristics and Timeliness of Corporate Financial Reporting in the Nigerian Insurance Industry

the insurance firms met four times per year and this complied with the requirements of Codes of Corporate Governance. Table 2 shows that a low number of women on the audit committee with some having no women at all. Insurance firms exhibit low profitability as evidenced by $3 \%$ return on total assets.

Table3. Correlation Matrix

\begin{tabular}{|l|l|l|l|l|l|l|l|l|}
\hline & Audlag & \multicolumn{1}{|c|}{ Acsz } & Acind & Acmeet & acgendiv & prof & lev & fsze \\
\hline Audlag & 1.0000 & & & & & & & \\
\hline Acsz & 0.1040 & 1.0000 & & & & & & \\
\hline Acind & -0.0593 & $0.3664^{*}$ & 1.0000 & & & & & \\
\hline Acmeet & $-0.3154^{*}$ & 0.0911 & 0.1040 & 1.0000 & & & & \\
\hline Acgendiv & 0.0065 & 0.1265 & 0.0204 & -0.0597 & 1.0000 & & & \\
\hline Prof & 0.0002 & -0.1323 & $-0.2615^{*}$ & -0.1084 & -0.1025 & 1.0000 & & \\
\hline Lev & 0.0163 & -0.0952 & -0.0825 & $-0.2794^{*}$ & -0.0928 & 0.0016 & 1.0000 & \\
\hline Fsze & -0.1223 & 0.0273 & -0.1226 & 0.1164 & -0.0754 & -0.1130 & 0.0662 & 1.0000 \\
\hline
\end{tabular}

Source: Authors' computations (2019)

The study conducted a pair wise correlation between the dependent and independent variables and displayed the result in Table 3. Audit committee independence, audit committee meeting frequency and firm size show negative correlation with timeliness measured by audit reporting lag. Only audit committee meeting frequency exhibits statistical significance with the dependent variable. Among the independent variables audit committee independence and size, Profitability and audit committee independence, Leverage and audit committee meeting frequency show significant correlation. A diagnostic test indicates multicollinearity does not constitute a serious problem to the result of the regression since the values of the Variance Inflation Factor (VIF) (Table 4) is within the tolerable limit of 10 [48].

Table4. Variance Inflation Factor

\begin{tabular}{|l|l|l|}
\hline \multicolumn{1}{|c|}{ Variable } & \multicolumn{1}{|c|}{ VIF } & \multicolumn{1}{c|}{ 1/VIF } \\
\hline acind & 1.27 & 0.786583 \\
\hline acsz & 1.19 & 0.840059 \\
\hline acmeet & 1.14 & 0.880802 \\
\hline Prof & 1.12 & 0.891793 \\
\hline lev & 1.12 & 0.895761 \\
\hline fsze & 1.08 & 0.929301 \\
\hline Acgendiv & 1.05 & 0.949388 \\
\hline Mean VIF & 1.14 & \\
\hline
\end{tabular}

Source: Authors' computations (2019)

\subsection{Regression Results}

The study tested four hypotheses and displayed the results in Table 5. The model shows good fit for the dependent and independent variables. Table 5 shows that $14 \%$ of the variance in timeliness is explained by the independent variables $\left(\mathrm{R}^{2}=0.0 .1430\right)$.

\subsubsection{Audit Committee Size and Timeliness in Financial Reporting}

Ho1 tested the relationship between audit committee size and timeliness in financial reporting. Table 5 reveals that audit committee size is positively related to timeliness in financial reporting $\left(\beta_{1}=\right.$ $18.17582)$. This is not statistically significant ( $\mathrm{p}$-value $=0.192)$. This result is contrary to our a priori expectation and evidence in some earlier studies [36, 37]. Consequently, Ho1 is not accepted. The implication of this finding is that as audit committee size increases, the number of days after year end and completion of external audit increases. The longer it takes to complete the external audit, the less timely is the financial report.

\subsubsection{Audit Committee Independence and Timeliness in Financial Reporting.}

The relationship between audit committee independence and timeliness in financial reporting was tested by Ho2. An examination of Table 5 shows that audit committee independence is negatively related to timeliness in financial reporting $\left(\beta_{2}=-16.02251\right)$ but this is not statistically significant at any of the conventional level ( $\mathrm{p}$-value $=0.453$ ). This finding suggests that as more non-executive 
Audit Committee Characteristics and Timeliness of Corporate Financial Reporting in the Nigerian Insurance Industry

directors sit on the audit committee, the number of days after year-end and completion of external audit declines. The lack of statistical significance leads to rejection of Ho2. One possible reason for lack of statistical significance is the fact that non-executive directors are independent of management in appearance but not in mental attitude.

Table5. Regression Result

\begin{tabular}{|c|c|c|c|c|c|c|}
\hline & & & & \multicolumn{2}{|c|}{ Number of obs $=$} & 60 \\
\hline & & & & \multicolumn{2}{|l|}{$\mathrm{F}(7, \quad 52)$} & 1.11 \\
\hline & & & & \multicolumn{2}{|l|}{ Prob> F } & 0.025 \\
\hline & & & & \multicolumn{2}{|l|}{ R-squared } & 0.1430 \\
\hline & & & & \multicolumn{2}{|l|}{ Root MSE } & 91.567 \\
\hline aodlag & Coef. & Robust Std. Err. & $\mathrm{t}$ & $\mathrm{P}>|\mathrm{t}|$ & \multicolumn{2}{|c|}{ [95\% Conf. Interval] } \\
\hline acsz & 18.17582 & 13.76316 & 1.32 & 0.192 & -9.441985 & 45.79362 \\
\hline acind & -16.02251 & 21.19497 & -0.76 & 0.453 & -58.55334 & 26.50832 \\
\hline acmeet & -32.89786 & 14.33122 & -2.30 & 0.026 & -61.65555 & -4.140173 \\
\hline acgendiv & -8.108741 & 19.52415 & -0.42 & 0.680 & -47.28681 & 31.06932 \\
\hline prof & -80.37236 & 190.8185 & -0.42 & 0.675 & -463.2777 & 302.533 \\
\hline lev & -31.05791 & 75.75245 & -0.41 & 0.683 & -183.0663 & 120.9505 \\
\hline fsze & -7.948427 & 11.44105 & -0.69 & 0.490 & -30.90657 & 15.00972 \\
\hline cons & 378.2564 & 201.5216 & 1.88 & 0.066 & -26.1262 & 782.6391 \\
\hline
\end{tabular}

Source: Authors' computations (2019)

\subsubsection{Audit Committee Meetings and Timeliness in Financial Reporting}

Ho3 tested the association between frequency of audit committee meetings and timeliness in financial reporting. Table 5 reveals a negative and highly significant association between the frequency of audit committee meeting and the number of days between year-end and the date of external auditor attestation of the financial statements $\left(\beta_{3}=-32.89786\right.$; $\mathrm{p}$-value $\left.=0.026\right)$. The result is in accordance our a priori expectation and therefore $\mathrm{Ho} 3$ is accepted. This result which finds empirical support in some prior studies $[24,43]$ implies insurance firms which have audit committee that meet more frequently experience more timely completion of external audit and publication of audited financial statements.

\subsubsection{Audit Committee Gender Diversity and Timeliness in Financial Reporting}

The fourth hypothesis of this study tested the relationship between audit committee gender diversity and timeliness in financial reporting. The result in Table 5 reveals a negative coefficient on audit committee gender diversity $\left(\beta_{3}=-8.108741\right)$. This indicates a negative relationship between audit committee gender diversity and timeliness in financial reporting as predicted. However, the relationship is statistically insignificant $(\mathrm{p}$-value $=0.680)$. Therefore Ho4 is rejected. The result is in disagreement with Gavious, Segev and Yosef [49] who found in sample of Israeli high technology firms listed in the USA that the presence of female director on the audit committee affected earnings management negatively. However, the result is in line with Ebirien [50] who found no significant association between female membership of corporate audit committees of non-financial firms listed on the Nigerian Stock Exchange and financial reporting quality.

\subsection{Control variables}

All the three control variables viz: profitability, leverage and firm size exhibit negative association with timeliness of corporate financial reporting but the association is not significant. The negative relationship between leverage and timeliness of corporate financial reporting could be because managers of such insurance firms would want to assure their creditors of their readiness to demonstrate transparency.

\section{CONCLUSION}

The study examined the extent to which audit committee characteristics affect timeliness of corporate financial reporting in the Nigerian insurance industry. Audit committee size, audit committee independence, audit committee frequency of meetings and audit committee gender diversity were the characteristics examined while controlling for profitability, leverage and firm size. Audit committee financial literacy was not studied because of data constraint. The study found that audit committee independence, meeting frequency and gender diversity were negatively related to timeliness in 
corporate financial reporting. However, only frequency of audit committee meeting produced significant relationship. Audit committee size showed positive and insignificant association contrary to a priori expectation. Two variables - profitability and leverage - recorded negative coefficient as predicted but lacked statistical significance. Firm size showed positive but insignificant relation confirming the mixed evidence in the literature.

The implication is for audit committees in the insurance industry to increase the frequency of meetings. Since audit committee independence and gender diversity followed the predicted sign, insurance firms should conduct due diligence on potential members to ensure they meet the quality of good monitors. It is recommended that this study be replicated using comparative data from deposit money banks and insurance firms.

\section{REFERENCES}

[1] International Accounting Standards Board (2018).IFRS Standards Issued at 1 January 2018. London: IFRS Foundation

[2] Abdulla, J. Y. A. (1996). The timeliness of Bahraini annual reports, Advances in International Accounting, 9, 73-88.

[3] Ahmed, K (2003). A comparative study of timeliness of corporate financial reporting in South Asia. Advances in International Accounting, 16, 17-42.

[4] Ashton, R. H, Paul, R. G., \& James, D.N. (1989), 'Audit delay and the timeliness of corporate reporting. Contemporary Accounting Research,5(2), 657-673.

[5] Ashton, R. H., Willingham, P. R., \& Elliot R .K. (1987). An empirical analysis of audit Delay. Journal of Accounting Research, (Autumn), 275-292.

[6] Carslaw, C. A.,.\& Kaplan, S. E. (1991). An examination of audit delay: Further evidence from New Zealand, Accounting and Business Research, (Winter), 21-32.

[7] Courtis, J.K. (1976). Relationships between timeliness in corporate reporting and corporate attributes. Accounting and Business Research (Winter), 204-219.

[8] Davies, B., \&Whittred, G. P. (1980). The association between selected corporate attributes and timeliness in corporate reporting: Further analysis. Abacus,16(1) 48-60.

[9] Dyer, J. C. \& McHugh, A. J. (1975). The timeliness of the Australian annual report. Journal of Accounting Research, 13, (2), 204-219.

[10] Gilling, M. D. (1977). Timeliness in corporate reporting: Some further comment. Accounting and Business Research, (Winter), 35-50.

[11] Imam S, Ahmed, Z. U., \& Khan, S. H. (2001). Association of audit delay and audit firms' International links: Evidence from Bangladesh. Managerial Auditing Journal, 16 (3), 129-133.

[12] Jaggi, B. \&Tsui, J. (1999). Determinants of audit report lag: Further evidence from Hong Kong. Accounting and Business Research,30(1), 17-28.

[13] Kinney, W. R. Jr., \& McDaniel, L. S (1993). Audit delay for firms correcting quarterly earnings. Auditing: A Journal of Practice \& Theory, Fall,12 (2), 135-142.

[14] Knechel, W. R., \& Payne, J. L. (2001). Additional evidence on audit report lags. Auditing: A Journal of Practice \& Theory,20(1), 137-146.

[15] Leventis, S. \&Weetman, P. (2004). Timeliness of financial reporting: applicability of disclosure theories in an emerging capital market. Accounting \& Business Research,34, 43-56.

[16] Ng, P. P. H. \& Tai, B. Y. K. (1994). An empirical examination of the determinants of audit delay in Hong Kong.British Accounting Review,26(1), 43-59.

[17] Owusu-Ansah, S. (2000). Timeliness of corporate financial reporting in emerging capital markets: Empirical evidence from Zimbabwe Stock Exchange. Accounting and Business Research,30(3), 241-254.

[18] Schwartz, K. B., \&Soo, B. S. (1996). The association between auditor changes and reporting Lags. Contemporary Accounting Research, 13(1):,353-370.

[19] Simnett, R., Aitken, M., Choo, F., \& Firth, M. (1995). The determinants of audit delay. Advances in Accounting, 13, 1-20.

[20] Soltani, B. (2002). Timeliness of corporate and audit reports: Some empirical evidence in the French context. The International Journal of Accounting, 37, 215-246.

[21] Bédard, J. \&Gendron, Y. (2010). Strengthening the financial reporting system: Can audit committees deliver? International Journal of Auditing, 14, 174-210 
Audit Committee Characteristics and Timeliness of Corporate Financial Reporting in the Nigerian Insurance Industry

[22] Spira, L. F. (2003). Audit committees: Begging the question? Corporate Governance: An International Review, 11, 180-188.

[23] Hashim, U. J. B. \&Rahman, R. B. A. (2010). Board independence, board diligence, board expertise and impact on audit report lag in Malaysian market. Retrieved from http://ssrn.com/ abstract=1717479

[24] Mohamad Nor, M. N., Shafie, R.,\& Wan-Hussin, W. N. (2010). Corporate governance and audit report lag in Malaysia, Asian Academy of Management Journal of Accounting and Finance, 6(2), 57 - 84.

[25] Sun, J., Liu, G., \&Lan, G. (2011). Does female directorship on independent audit committees constrain earnings management? Journal of Business Ethics, 99, 369-382.

[26] Agabi, C. (2013, May 29). Nigeria: 55 insurance companies yet to submit 2012 accounts. Vangaurd.

[27] Njoku, I., Adegboye, K. \&Onuoha, R. (2012, May 8 ). Poor perception: Bane of property insurance, Vanguard.

[28] Ebirien, G, I., \&Nwanyanwu, L. A. (2017). Earnings quality of firms in the Nigerian financial services sector.European Journal of Accounting, Auditing and Finance Research, 5 (4), 54-64.

[29] Ismail, K., Nor, I., \& Chandler, R. (2003). The timeliness of quarterly financial reports of companies in Malaysia. Retrieved from http://papers.ssrn.com/sol.3/papers.cfm? Abstract_id=415047.

[30] Leventis, S., Weetman, P. \&Caramanis, C. (2005). Determinants of audit report lag: Some evidence from the Athens Stock Exchange. International Journal of Auditing, 9(1), 45-58.

[31] Jensen, M. C. \&Meckling, W. H. (1976). Theory of the firm: managerial behavior, agency costs, and ownership structure. Journal of Financial Economics, 3 (October), 305-360.

[32] Watts, R. L., \& Zimmerman, J. L., (1986). Positive Accounting Theory. Englewood Cliffs, NJ, Prentice-Hall.

[33] Hope, O.-K., \& Thomas, W. B. (2008). Managerial empire building and firm disclosure, Journal of Accounting Research,46(3), 591-626.

[34] Kothari, S. P., Shu, S. \&Wysocki, P. D. (2009). Do managers withhold bad news? Journal of Accounting Research,47(1), 241-276.

[35] Kalbers, L. P., \& Fogarty, T. J. (1993), Audit committee effectiveness: an empirical investigation of the contribution of power. Auditing: A Journal of Practice \& Theory, 12(1), 24-40.

[36] Pucheta-Martinez, M. \& Fuentes, C. (2007). The impact of audit committee characteristics on the enhancement of the quality of financial reporting: an empirical study in the Spanish context. Corporate Governance, 15( 6), 1394-412.

[37] Rahmat, M. M.,Iskandar, T. M., \&Saleh, N. M. (2009). Audit committee characteristics in financially distressed and non-distressed companies.Managerial Auditing Journal,24(7), 624- 638.

[38] Abbott L. J., Parker S. \& Peters, G. F. (2004), Audit committee characteristics and restatements, Auditing: A Journal of Practice and Theory, 23(1): 69-87.

[39] Bedard, J., Chtourou, S. M., \&Courteau, L. (2004). The effect of audit committee expertise, independence, and activity on aggressive earnings management. Auditing: AJournal of Practice \& Theory,23(2), 13-35.

[40] National Insurance Commission of Nigeria (2009). Code of Good Corporate Governance for the Insurance Industry in Nigeria. Retrieved from https://www.naicom.gov.ng .

[41] Abbott. L.J..Park.Y. \& Parker.S. (2000).The effects of audit committee activity and independence on corporate fraud. Managerial Finance,26(11), 55-67.

[42] Ebirien , G. I. (2014b). Female membership of corporate audit committees and financial reporting quality, Paper presented at $4^{\text {th }}$ African Accounting and Finance Association Conference: 3-4september 2014 at the Lord Charles Hotel, Sommerset West, Western Cape. South Africa.

[43] Karamanou, I., \&Vafeas, N. (2005). The association between corporate boards, audit committees, and management earnings forecasts: an empirical analysis. Journal of Accounting Research, 43(3), 453-486.

[44] Kaplan, S., Pany, K., Samuels, J. \& Zhang, J. (2009). An examination of the association between gender and reporting intentions for fraudulent financial reporting.Journal of Business Ethics, 87, 15-30.

[45] Adams, R. \& Ferreira, D. (2009). Women in the boardroom and their impact on governance and performance. Journal of Financial Economics, 94(2), 291-309.

[46] Gul, F. A. Srinidhi, B. \& Ng, A. C. (2011). Does board gender diversity improve the informativeness of stock prices? Journal of Accounting and Economics, 51, 314-338.

[47] Iyoha, F.O. (2012). Company attributes and the timeliness of financial reporting in Nigeria, Business Intelligence Journal,5(1), 41-49.

[48] Hair, J. F., Black, W. C., Babin, B. J. \& Anderson, R. E. (2010) Multivariate Data Analysis: A Global Perspective (7th ed.), Pearson Prentice Hall: Upper Saddle River, New Jersey. 
Audit Committee Characteristics and Timeliness of Corporate Financial Reporting in the Nigerian Insurance Industry

[49] Gavious, I., Segev, H., \&Yosef, R. (2012). Female directors and earnings management in high-technology firms.Pacific Accounting Review, 24(1), 4 - 32.

[50] Ebirien, G. I. (2014). Board credit committee characteristics and the loan portfolio quality of Nigerian deposit money banks, West African Journal of Business and Management Sciences (Nigerian Edition) (Special Edition), 3(1), 11-22.

Citation: Gospel J. Chukwu, Ngozi Nwabochi. "Audit Committee Characteristics and Timeliness of Corporate Financial Reporting in the Nigerian Insurance Industry" International Journal of Managerial Studies and Research (IJMSR), vol 7, no. 4, 2019, pp. 86-95. doi: http://dx.doi.org/10. 20431/23490349.0704012.

Copyright: (C) 2019 Authors. This is an open-access article distributed under the terms of the Creative Commons Attribution License, which permits unrestricted use, distribution, and reproduction in any medium, provided the original author and source are credited. 